\title{
Agricultural Research for Resource-Poor Farmers: The Farmer-First-and-Last Model
}

\author{
Robert Chambers \\ Institute of Development Studies, University of Sussex, Brighton BNI 9RE, \\ Sussex, Great Britain \\ and \\ B. P. Ghildyal \\ Ford Foundation, 55 Lodi Estate. New Delhi 110003, India
}

(Received: 3 December, 1984)

\begin{abstract}
$S U M M A R Y$
Rural poverty is much less a problem of total food availability than of who produces the food and who has the income to buy' it. A high priority' is therefore to enable the tens of millions of resource-poor farm families to increase their production and improve its stability. The normal "transferof-technology" (TOT) model for agricultural research has built-in biases "1hich favour resource-rich farmers whose conditions resemble those of research stations. TOT approaches have been modified through on-farm trials and demonstrations but the basic model and approach remain the same. A second emerging model is 'farmer-first-and-last' (FFL). This starts and ends with the farm family and the farming system. It begins with holistic and interdisciplinary appraisal of farm families' resources, needs and problems, and continues with on-farm and with-farmer $R$ and $D$, with scientists, experiment stations and laboratories in a consultancy and referral role. FFL fits the needs and opportunities of resource-poor farm families better than TOT, but there are obstacles to its development and introduction. These can be tackled step-by-step, through combinations of methodological innovation, interdisciplinarity, including the social sciences, and provision of suitable resources, rewards and raining. FFL approaches promise a greater contribution from agricultural research to the eradication of nural poverty.
\end{abstract}


'The future of our agriculture... depends on the success with which we can help the small and illiterate farmers to take the many small steps which alone can lead to improved methods of farming.'

M. S. Swaminathan

(reference 38, p. 63)

\section{RESOURCE-POOR FARMERS: NEED AND OPPORTUNITY}

The economic and social benefits from agricultural research can be extremely high. Benefit-cost ratios can exceed those for almost any other form of investment. The dramatic advances in productivity achieved in the Green Revolution in irrigated wheat in Northwest India in the late 1960s present what is perhaps the internationally best known example. It is true that the preconditions (groundwater, canal water, electrification, infrastructure, land consolidation, potential access to inputs, etc.) were in place to provide an almost ideal environment for the new stiff- and shortstrawed HYVs of wheat when they were introduced. But behind the success also lay the imagination of scientists who brought to bear their powerful skills on a perceived need and opportunity. The argument we will develop in this paper is that agricultural scientists today are also faced with a need and an opportunity; that it is different and that it requires a different solution through new methodology and skills.

The Green Revolution strategy was evolved in an era when the problem of poverty and hunger was seen largely as a problem of production, of growing more food. Since lack of food could lead to undernutrition and starvation, it seemed logical to attribute undernutrition and starvation, when they were found, to food shortages. If enough food could be produced, hunger would be vanquished. Given the diagnosis, the strategy was well-conceived. It concentrated on those farmers and those areas with the greatest apparent potential for producing more food. If it favoured the better-off farmers and the better-endowed areas, this was justified since they presented the conditions in which the new high-yielding technologies, generated on research stations, could most readily be adopted. The Intensive Agricultural District Programme in India is an example that was thought out on these lines, and targeted to districts with good irrigation and a good infrastructure. It was part of a policy of consciously betting on the strong, and its successes in Northwest India are well known. 
In the past decade there have been significant shifts in understanding of poverty and hunger and in priorities. Increasing total food production remains a vital objective in many Third World countries, most acutely in Sub-Saharan Africa, but also in India and elsewhere. But it is now recognised that increased food production alone will not overcome rural poverty. In the new understanding, most elegantly and eloquently demonstrated by Amartya Sen, ${ }^{34.35}$ famines and family food shortages result much less from the shortages of food supply, and much more from lack of means to grow it or of income to buy it. This is especially so in India where, as a result of public information, political commitment and good organisation (and in contrast with some past experience in China) food supply shortages have not been permitted to occur on any scale. In the words of Swaminathan: 'Famines in India are often famines of work rather than of food, since when work can be had and paid for, food is always forthcoming'. ${ }^{39}$ For overcoming rural poverty, much more important than total food produced is who produces it and who can obtain it. This directs attention towards the needs and interests of those who were largely by-passed by the Green Revolution technologies, the tens of millions of farm families who are resource poor.

A resource-poor farm family is defined as one whose resources of land, water, labour and capital do not currently permit a decent and secure family livelihood. In India, such families include many, though not all, of those with marginal ( $0-1 \mathrm{ha}$ ) and small ( $1-2 \mathrm{ha}$ ) farm holdings, and many others with more than 2 ha but whose land is infertile, vulnerable to floods or erosion, or subject to low and unreliable rainfall. (The abbreviation $\mathrm{RPF}$ is used to refer to resource-poor farm or resource-poor farmer, according to context, and RRF to refer to resource-rich farm or farmer.)

Three major reasons can be given for orienting more agricultural research to serve the interests and fit the conditions of RPF families, so defined.

\section{Social justice}

RPF families include many of the poorest and most vulnerable people. Their numbers are very large. In India, at least three-quarters of operational holdings are less than $2 \mathrm{ha}^{20}$ and they must now (1984) number over 60 million. However, some farmers with less than 2 ha (e.g. with reliable irrigation and good soils) are not R PFs, and some with more than 2 ha (e.g. with poor soils and unreliable rainfed conditions) are 
RPFs. If these are taken as cancelling out, we have, very roughly, some 60 million families, or about 300 million people, in this category in India. In Sub-Saharan Africa, similarly, most farm families are resource-poor, not least because there is much less irrigation than in Asia. Substantial breakthroughs in adoptable technology for only, say, 10-20 per cent of RPF families in India or Sub-Saharan Africa would thus have a massive impact on poverty in numbers of people who would benefit.

\section{Production}

The social justice argument is enough in itself. But, in addition, greater food production is a very high priority in Sub-Saharan Africa, and much of the potential for this has to be sought on R PFs. In India, RP farms comprise perhaps between a third and a half of the area of land under operational holdings. Much of this is rainfed, which constitutes some 75 per cent of the cropped area of the country, contributing about 42 per cent of total food production. The production potential on RPFs will almost always be less than on RRFs, but past relative neglect and failures promise that whatever potential exists for increased production is still largely unexploited. There is also scope for reducing risks for RPFs, which is important for them, besides enabling them to produce more.

\section{Employment}

Improved farming systems for R PFs should generate productive work around more of the year. High proportions of additional income among the poor, such as RPF families, are also spent on locally produced consumption and capital goods, and these purchases, in turn, generate employment for others.

The question, then, is how can agricultural research be oriented efficiently to serve the needs and conditions of RPF families? To seek answers to that question, we will examine two contrasting models for agricultural research.

\section{MODEL A: TRANSFER-OF-TECHNOLOGY*}

The transfer-of-technology (TOT) model is deeply embedded in the thinking of many professions and disciplines around the world. It is part of the structure of centralised knowledge in which power, prestige and

* The model is also described by Robert Rhoades and his colleagues at CIP (The International Potato Centre), Peru, as the vertical transfer model. ${ }^{32}$ 
professional skills are concentrated in well-informed 'cores' or centres." These cores or centres generate new technology which then spreads (or does not spread) to the peripheries. Highly trained civil, mechanical and agricultural engineers, medical scientists, agronomists and others develop technologies in laboratories, workshops and experiment stations, and then attempt to transfer them to would-be clients. This approach has had immense successes in industry and agriculture with resource-rich clients. For example, the development of mechanisation through combine harvesters, tractors and threshers by agricultural engineers, and the development of high-yielding technological packages by plant-breeders and others have enabled many of the resource rich to increase their productivity and profitability. But the approach has also had severe shortcomings for would-be clients who are resource poor.

In most agricultural sciences, the centres in which research is conducted are experimental stations, glasshouses and laboratories, supported by back-up services, with provision for controlled conditions, with excellent access to inputs, without significant cost or labour constraints, and without the requirement that a crop must be marketed and make a profit. Scientists in experiment stations, glasshouses and laboratories generate, or test, new technologies and then pass them over to extension services to transmit to farmers. In political and scientific meetings, speeches about the vital importance of the transfer of technology are a predictable feature. Physical, biological and social scientists, alike, have held the transfer of technology from scientists to farmers to be a central concern. The model has, until recently, been part of the valued and respected structure of thinking of almost all professionals concerned with agricultural research, not only in India, but worldwide.

In practice, as is now only too well known, the transfer of technology often presents intractable problems with resource-poor farmers. When RPFs did not adopt 'good' new technology, both social scientists and agricultural scientists at first attributed this to ignorance. The large-scale social science research in India in the 1960s on 'diffusion of innovations' assumed that the technologies were good and appropriate. A major premise was that, if small farmers did not adopt them, it was because they did not know about them, or did not know enough about them. The prescription that followed was for more and better extension, as the Extension Directorates of Indian Agricultural Universities testify. The standard phrase, so often repeated, that 'We must educate the farmer', * For this perspective and argument presented in more detail, see Chambers, ${ }^{11} \mathrm{pp} .4-10$, $75-82$ and $168-169$. 
exactly reflects the underlying pattern of thought. 'We' have the relevant knowledge. Ignorant farmers do not have it. We must teach the ignorant farmers.

But there is now much evidence and understanding that when R PFs do not adopt technology it is usually not from ignorance but because the technology does not fit their needs and their physical, social and economic conditions. Technologies, whether biological or physical, bear the imprint of the conditions in which they are generated. They are then adoptable in similar conditions, but of ten not adoptable where conditions differ. As it happens, many conditions on research experiment stations

TABLE 1

Typical Contrasts in Physical Conditions ${ }^{a}$ (Not all apply all the time, but most apply most of the time)

\begin{tabular}{|c|c|c|c|}
\hline & $\begin{array}{l}\text { Research } \\
\text { experimem } \\
\text { station }\end{array}$ & $\begin{array}{l}\text { Resource-rich } \\
\text { farm }(R R F)\end{array}$ & $\begin{array}{l}\text { Resource-poor } \\
\text { farm }(R P F)\end{array}$ \\
\hline Topography & $\begin{array}{l}\text { Flat or sometimes } \\
\text { terraced }\end{array}$ & $\begin{array}{l}\text { Flat or sometimes } \\
\text { terraced }\end{array}$ & $\begin{array}{l}\text { Often undulating } \\
\text { and sloping }\end{array}$ \\
\hline Soils & $\begin{array}{l}\text { Deep, fertile, } \\
\text { no constraints }\end{array}$ & $\begin{array}{l}\text { Deep, fertile, } \\
\text { no constraints }\end{array}$ & $\begin{array}{l}\text { Shallow, infertile, } \\
\text { often severe } \\
\text { constraints }\end{array}$ \\
\hline $\begin{array}{l}\text { Macro- and micro- } \\
\text { nutrient deficiency }\end{array}$ & Rare, remediable & Occasional & Quite common \\
\hline Plot size and nature & $\begin{array}{l}\text { Large, square. } \\
\text { Small bunds }\end{array}$ & $\begin{array}{l}\text { Large. } \\
\text { Small bunds }\end{array}$ & $\begin{array}{l}\text { Small, irregular. } \\
\text { Bunds larger where } \\
\text { present }\end{array}$ \\
\hline Hazards & Nil or few & $\begin{array}{l}\text { Few, usually } \\
\text { controllable }\end{array}$ & $\begin{array}{l}\text { More common- } \\
\text { floods, droughts, } \\
\text { animals grazing } \\
\text { crops, etc. }\end{array}$ \\
\hline Irrigation & Usually & Usually available & Often non-existent \\
\hline $\begin{array}{l}\text { Size of management } \\
\text { unit }\end{array}$ & Large, contiguous & $\begin{array}{l}\text { Large or medium, } \\
\text { contiguous }\end{array}$ & $\begin{array}{l}\text { Small, often scattered } \\
\text { and fragmented }\end{array}$ \\
\hline Diseases, pests, weeds & Controlled & Controlled & $\begin{array}{l}\text { Crops vulnerable to } \\
\text { infestation }\end{array}$ \\
\hline
\end{tabular}

a Tables 1 and 2 have been slightly modified in the light of the comparison of experiment stations and farmers' fields in Catling ${ }^{9}$ p. 11 . Table 1 refers especially to South Asian conditions. 
TABLE 2

Typical Contrasts in Social and Economic Conditions (Not all apply all the time, but most apply most of the time)

\begin{tabular}{|c|c|c|c|}
\hline & $\begin{array}{l}\text { Research } \\
\text { experimem } \\
\text { station }\end{array}$ & $R R F$ family & RPF family \\
\hline $\begin{array}{l}\text { Access to seeds, } \\
\text { fertilisers, pesticides } \\
\text { and other purchased } \\
\text { inputs }\end{array}$ & Unlimited, reliable & High, reliable & Low, unreliable \\
\hline Seeds used & High quality & $\begin{array}{l}\text { Purchased high } \\
\text { quality }\end{array}$ & Own seed \\
\hline $\begin{array}{l}\text { Access to credit } \\
\text { when needed }\end{array}$ & Unlimited & Good access & $\begin{array}{l}\text { Poor access and } \\
\text { seasonal shortages of } \\
\text { cash when most } \\
\text { needed }\end{array}$ \\
\hline $\begin{array}{l}\text { Irrigation, where } \\
\text { facilities exist }\end{array}$ & $\begin{array}{l}\text { Fully controlled } \\
\text { by research } \\
\text { station }\end{array}$ & $\begin{array}{l}\text { Controlled by } \\
\text { farmer or by } \\
\text { others on whom } \\
\text { he can rely }\end{array}$ & $\begin{array}{l}\text { Controlled by others, } \\
\text { less reliable }\end{array}$ \\
\hline Labour & $\begin{array}{l}\text { Unlimited, no } \\
\text { constraint }\end{array}$ & $\begin{array}{l}\text { Hired, few } \\
\text { constraints }\end{array}$ & $\begin{array}{l}\text { Family, constraining } \\
\text { at seasonal peaks }\end{array}$ \\
\hline Prices & Irrelevant & $\begin{array}{l}\text { Lower than RPF } \\
\text { for inputs } \\
\text { Higher than RPF } \\
\text { for outputs }\end{array}$ & $\begin{array}{l}\text { Higher than RRF } \\
\text { for inputs } \\
\text { Lower than RRF } \\
\text { for outputs }\end{array}$ \\
\hline $\begin{array}{l}\text { Priority for food } \\
\text { production }\end{array}$ & Neutral & Low & High \\
\hline
\end{tabular}

and in laboratories are close to those of RRFs and sharply different from those of RPFs. The contrasts are presented in Tables 1 and 2.

As a result of the contrasts in Tables $I$ and 2 , the conclusion could be a final entry in each Table, as shown below.

Research
experimem station

Appropriateness of technology generated on research experiment stations for the receiving environment 
There are other well known contrasts. RRFs are primarily concerned with commercial production and, in their better controlled and more favourable environments, they are not exposed to risk as a dominant management factor. R PFs, in contrast, have assurance of their own food supply as their highest priority, often with cash from sales of produce as a highly desirable, but secondary, benefit; and in their poorly controlled and unfavourable environments, they are much preoccupied with minimising risk. Paradoxically, too, resource-rich farming systems are often simpler, with monocropping more than intercropping, with larger fields, fewer varieties of plants grown and less significant crop-animal interactions. When these contrasts, and those in the Tables, are taken together, it is easier to understand why so much new technology has been adopted by the resource rich and not by the resource poor. Most nonadoption by RPF families can be explained by the inappropriateness to their special needs and resources of the technology to be transferred.

Nevertheless, the TOT model remains dominant, almost universal. Before examining a more promising emergent model, it will be useful to ask why this is so. Four main reasons can be suggested.

\section{The proven power of the model}

The TOT model has demonstrated strengths, especially in plant breeding and varietal development. Much basic research requires controlled conditions and precise and difficult measurements which are best achieved in laboratories and on research stations. The model has contributed to great and conspicuous increases in food production, most notably in the Green Revolution.

\section{International transfer of the model}

The TOT model has itself been transferred and reinforced internationally. The approaches of the Land Grant Colleges in the United States have been transferred to the Agricultural Universities of India. In the United States the model developed technology primarily for the resource rich. The high input capital-intensive monocropping generated on research stations fitted their conditions and was one factor in displacing smaller scale more subsistence farming systems and families. Many of the resource poor could not make it and sold out, but could then move to the booming cities which were, on the whole, able to provide them with livelihoods. Scientists 
from the rich North have thus little reason to question the model. For them it has worked, and continues to work. They do not have to face the problem of tens of millions of resource-poor subsistence or near subsistence farmers for whom the model does not fit, and for whom migration to the cities is not a feasible large-scale solution.

\section{Scientists' rewards and motivations}

There are strong professional reasons why agricultural scientists should follow the TOT model. At the international and national levels, there is the prestige attributed to 'high' technology, seed breeding and expensive and sophisticated equipment and methods of research. [Norman Borlaug received the Nobel Prize for applications of this model.] Then there is personal convenience in working in office and laboratory, and on a research experiment station, rather than on-farm or with-farmer. Further, for gaining professional recognition and for minimising risk of not gaining it through failed experiments, in-laboratory and on-station work in controlled environments is to be preferred. The environments of resource-poor farmers are very complex. There are many stresses with many interactions. Moreover, the research methodology for such environments is not well established. It is safer for professional advancement and recognition not to share the farmers' risks. At a deeper psychological level, the values and thinking which place the scientist on a pedestal as a pundit, generating new knowledge and dispensing it to the surrounding masses, are personally gratifying.

\section{Interlocking biases against the resource poor}

Scientists' rewards and motivations interlock with other well known biases of professional behaviour, contact and perception towards those rural people who are better off, to the neglect of those who are poorer.* Scientists are often urban based. Their rural visits have spatial biasesurban, tarmac, and roadside, and towards large villages and village centres - concentrating attention where the better-off tend to be located. Other biases concern contact with those with higher status, more influence, greater wealth and better education-in short, the resource rich, to the neglect of those with lower status, less influence, less wealth

${ }^{*}$ For a more detailed description of these and other biases, see Chambers, ${ }^{11}$ pp. $7-25$ and $171-9$. 
and less education - in short, the resource poor.* Scientists meet adopters more than non-adopters. It is progressive, RRFs on whose land demonstrations are most often laid out, and who provide hospitality and cups of tea for visiting officials. Then there are also biases of modernity and capital-intensity: it is the tractor, the pump, the thresher, the inorganic fertiliser and other purchased inputs, which attract attention. In their own backgrounds, too, many scientists come from relatively rich families, of ten urban, and few have known life in an RPF family. They are also "seasonproofed' in that they do not personally experience, as a farmer does, the vagaries and difficulties of dependence on the rains. Nor does their income depend on uncertain agriculture: their pay cheques are regular and monthly, not seasonal and variable.

When these and other factors are taken into account, it is more than understandable that agricultural scientists have difficulty appreciating RPF conditions and that they do not doubt that the TOT model is appropriate for their work. They have good reason to embrace it and little reason to question it: they rarely meet or interact with RPFs; their research is heavily weighted towards the conditions of the resource rich and it is from the resource rich who adopt, much more than from the resource poor who do not adopt, that they get most of their feedback on the value of their technology.

\section{The model modified}

In the light of disappointing experience with transfer of technology to RPFs, many modifications have been made to the TOT model. No summary description can do justice to these, but some, at least, deserve to be mentioned to indicate the scale and scope of the effort that has been made, and to set subsequent discussion in perspective.

* RRFs, or those likely to be RRFs, are considered to be the better informants. Thus Shaner et $a l^{36}$ (pp. 74-5), in suggesting interviewees in reconnaissance surveys, list: farmers who hold leadership positions; farmers identified by the extension service who will often have tried recommended practices; innovative farmers who have successfully developed improved technologies: women farmers who are both members and heads of households and 'above all, farmers who are representative of major farming systems in the area'.

A case can be made out for this list. But the first three types of informant are more likely to be RRFs than RPFs, and the women and the farmers representative of major farming systems may exhibit an RRF bias unless a deliberate and explicit attempt is made to identify R PFs. 
Some of the changes to the TOT model have taken the form of organising feedback to researchers on problems in adapting and adopting their recommendations. Thus, $\mathrm{T}$ and $\mathrm{V}$ provides for feedback from extension to research and is designed to generate demands on the research system for recommendations. ${ }^{4}$ IRRI's constraints research is another example where yield gaps are measured between performance on the research station and on farmers' fields and then attempts made to see how farmers' ${ }^{14}$ conditions could be altered to enable them to do better or how research priorities should be changed. The Operational Research Project (ORP) in India also illustrates this pattern. It is seen as a step in the process of technology generation which provides scientists with opportunities to test, verify and perfect their new technology while it is operated under field conditions. In the words of recent guidelines, 'It is not experimentation but only a step to verify the results of successful experimentation conducted elsewhere'. In all these three examples- $T$ and V, IRRI's constraints research and the OR P in India-the research comes first to develop the technology which may then be adapted and perfected following experience with its use in on-farm conditions. Despite modifications for feedback, the basic TOT structure remains unchanged. ${ }^{16}$

The TOT model and modifications to it are well exemplified in major agricultural research programmes in India. ${ }^{18}$ For example, research on major food crops is conducted through All India Coordinated Crops Improvement Projects located in Agricultural Universities and Central Institutes. The experiments are primarily carried out at experiment stations, with emphasis on varietal improvement, production technology and plant protection. Under different All India Coordinated Soil and Water Management Projects, special technologies are developed for specific problem areas, such as reclamation technology and dryland technology. ${ }^{19}$ Operational Research Projects have been implemented for specific problem areas such as the management of alkali soils, composite fish culture, control of cotton pests, dryland agriculture for semi-arid red soils, and so on. ${ }^{33}$ For small, marginal and landless agricultural labourers, the 'Lab-to-Land' programme was started. The major thrust was the introduction of new technologies for diversification of labour use and the introduction of supplementary sources of income such as apiculture, aquaculture, sericulture, and home crafts. A number of 'Transfer of Technology Centres' have been created in Agricultural Universities, Central Institutes, and other government organisations and voluntary agencies. 
These programmes present progressive modifications of the model and attempts to offset its biases. There has been increasing emphasis on onfarm trials and demonstrations. The All-India Coordinated Project on National Demonstrations has been organised and implemented. The attention directed to problem environments focuses on farmers who are often, by definition, resource poor. The 'Lab-to-Land' programme is explicitly directed towards them. The establishment of centres in backward areas for training farmers in new technology follows the same pattern of a thrust towards the resource poor.

It is, however, fair to say that the outcome, in terms of adoption of new technology by RPFs, has been disappointing. The old explanation of 'ignorance' on the part of the RPFs has been partly superseded by attempts to understand farmers' conditions and constraints. Technology generated by research is tested on farmers' fields under farmers' management conditions. The large yield gaps between crop yields obtained in National Demonstrations are compared with the much lower yields actually obtained by farmers. Yield gap analysis is then undertaken to identify the relative significance of different constraints which face farmers. This is a big step forward from attributing non-adoption mainly to ignorance.

But the basic model remains the same. Priorities are set by scientists relying on their professional understanding and criteria. Research is conducted in central locations and then extended outwards, tested and modified. There has, it is true, been increasing emphasis on feedback from the field. There are farmers' days at Indian Agricultural Universities and Institutes. The $\mathrm{T}$ and $\mathrm{V}$ system encourages some closer contact between agricultural research scientists and farmers. But throughout, the farmers from whom there is feedback tend to be precisely those best placed to benefit from the technology generated. It is scarcely to be expected that many RPFs, illiterate and powerless as they so often are, will be able to demand the services of agricultural scientists, or will go to farmers' days and speak up about their problems. What feedback comes is mainly from the progressive and better-off farmers and does not throw into question the basic structure of research activity. The RPFs, whose needs and resources the technology does not fit, are precisely those who do not come and speak up, who are not sought out and from whom scientists are least able or inclined to learn.

Our conclusion is that, for all its manifest power to achieve results on experiment stations and on the fields of RRF farmers, the TOT model of agricultural research does not encourage scientists to learn from RPFs. 
Even in its modifications it has not shown itself well suited to generating technology which they can and will adopt.

\section{MODEL B: FARMER-FIRST-AND-LAST}

The farmer-first-and-last (FFL) model entails fundamental reversals of learning and location. These, we argue, are necessary if research, and the technology it generates, are better to fit the needs and conditions of R PF families.

FFL differs from TOT in starting, not with scientists and their perceptions and priorities, but with R PF families and theirs. It begins with a systematic process of scientists learning from, and understanding, RPF families, their resources, needs and problems. The main locus of research and learning is the resource-poor farm, rather than the research station and the laboratory. Research problems and priorities are identified by the needs and opportunities of the farm family rather than by the professional preferences of the scientist. The research station and the laboratory have a referral and consultancy role, secondary to, and serving, the R PF family. The criterion of excellence is not the rigour of on-station or in-laboratory research, or yields in research station or resource-rich farmer conditions, but the more rigorous test of whether new practices spread among the resource poor.

The sharp distinction which we see between TOT and FFL has been blurred by some of the many meanings given to 'farming systems' and 'farming systems research'* Farming systems research sometimes means 'upstream' research, in which elements of a farming system are evolved and investigated on an experiment station. This is a TOT approach. In contrast, there is 'downstream' farming systems research which starts and ends with farmers, beginning with systematic attempts to understand the farm and farming system. This is an FFL approach.

\section{Four prototypes and variants}

FFL approaches are not entirely new, but they have not been fully explored, fitted together and evolved. Several variants have been

* For useful reviews see Norman. ${ }^{25}$ Gilbert et $a l .{ }^{15}$ Byerlee et $a l .,{ }^{8}$ Shaner et $a l . .{ }^{36}$ and Biggs. ${ }^{5}$ For salutory cautions not to regard farming systems research as a panacea, see Nygaard and Rassam. ${ }^{26}$ 
described in the literature which we have examined. They are still being developed and so can be considered prototypes. They include CIMMYT's approach to planning technologies appropriate to farmers, ${ }^{7,13}$ the Sondeo method of rapid appraisal, ${ }^{17}$ ICRAF's D and D (diagnosis and design) for agro-forestry ${ }^{21.28}$ and the farmer-back-to-farmer methodology of CIP. ${ }^{30}$ These will be briefly described and then compared.

\section{CIMMYT}

The CIMMYT approach emphasises the farmer as the primary client of agricultural research, and farmer circumstances as the basis for planning research. It pays much attention to the methods whereby farmer circumstances are identified. Farmers are grouped into 'recommendation domains-groups of farmers for whom more or less the same recommendations can be made. There is a focus on a target crop. Rapid appraisals are conducted by an agronomist and an economist working together. Background information is assembled. An exploratory survey is carried out, using a check list of farmer circumstances, classified as natural circumstances; external socio-economic circumstances of markets and institutions; farmers' goals and resources; relevant features of the total farming system, and description of production practices for the target crop. $^{7}$ This is followed by a formal verification survey with a questionnaire (which, however, may well be superfluous after a well conducted exploratory survey). Analysis of data and prescreening of technological components then lead to the identification of 'best bets' and on-farm experiments with these.

\section{Sondeo}

The Sondeo approach, developed by Hildebrand in Guatemala, is strongest in its technique for the creative combination of disciplines in rapid appraisal to generate new technology. ${ }^{17} \mathrm{~A}$ zone with homogeneous farming practices is identified, in which there are to be farm trials of technologies which are, as yet, not specified. A team leader and ten team members-five of them agronomists and animal scientists, and five from socio-economics - conduct a very rapid appraisal. They work in pairsone agronomist or animal scientist with one socio-economist - changing partners each day for five days. They visit the area, and interview farmers and others, attempting to understand the farming system and to identify 
feasible and suitable improvements, and all brainstorm together each evening. At the end of the five days, many three-cornered discussionsbetween farmers, social scientists and biological scientists-have contributed to proposals for improved farm practices. A report is written under pressure and provides proposed innovations for the Technology Testing Team which then works in the area with on-farm and with-farm trials.

\section{ICRAF's $D$ and $D$}

ICRAF's diagnosis and design ( $D$ and $D$ ) methodology sets out to identify promising candidate agro-forestry technologies. Major emphasis is placed on the farm household management unit and the satisfaction of its needs. The methodology also seeks to address a broader range of production and conservation objectives than most farming systems research, emphasising productivity, sustainability and adoptability. A minimal team includes one or more representatives of agricultural science (general agronomy, horticulture and livestock sciences), forestry (in the broadest sense), social science (sociology/anthropology, human geography and economics) and natural sciences concerned with land resource survey (ecology, soils science, climatology). The application of D and D procedures by a multidisciplinary team usually entails about two weeks to carry out the diagnostic survey, analyze the results and develop appropriate design concepts for agro-forestry interventions to improve the existing land use system. There is a four-stage procedure-prediagnostic, diagnostic, design and follow-up planning. The D and D procedures are seen as part of a continuing learning process and may be repeated.

\section{CIP's farmer-back-to-farmer}

The original farmer-back-to-farmer research was conducted on potato storage in Peru by biological scientists and an anthropologist following 25 years of failure in potato storage work. ${ }^{30.31}$ The anthropologist learnt about farm families' objectives and their knowledge of, and problems with, potato storage, and acted as a link between them and the biological scientists, bringing the latter into direct learning contact with the farmers. There were four stages-establishing a common definition of the problem; interdisciplinary team research seeking a solution; testing and adaptation of the proposed technology on-farm, with farmers contributing 
ideas and 'farmer evaluation: the last judgement'. The result was an improved and adoptable technology which meets farmers' objectives, used materials to which they had access, fitted in with their traditional house design and, above all, was adopted by them. A key element was changes of perception and priority on the part of the scientists. For example, what appeared losses to scientists were not necessarily losses to farmers, who had uses for shrivelled or spoiled potatoes. One biological scientist reflected later:

'I was not totally convinced of the anthropologist's argument, although he certainly made me think about what I was doing. We (biological scientists) hadn't even really talked to a farmer about the problems we were working on. We were doing research about a problem from a distance, not research to solve a problem. When I finally went with him to visit farmers I could see he was right, but only partially. ${ }^{30}$

\section{The prototypes analysed}

Farming Systems Research (FSR), in its various manifestations, is often described in terms of stepwise sequences. Shaner et al. ${ }^{36}$ emphasise five activities: (i) target and research area selection; (ii) problem identification and development of a research base; (iii) planning on-farm research; (iv) on-farm research and analysis and (v) extension of results, with collaboration between these and extension and the experiment station. Maxwell $^{22}$ with reference to Norman ${ }^{24}$ lists activities in a slightly different classification as to identify recommendation domains, diagnosis, the generation of recommendations, implementation and monitoring and evaluation. He has also designed a simple algorithm for farming systems research. ${ }^{23}$ The CIMMYT and ICRAF approaches to FFL are also set out as logical sequences of activities.

To what extent sequences should be followed will, however, vary by circumstances. The quickest and most cost-effective approach may often be inventive, opportunistic and iterative, not necessarily following a fixed order of activities. Thus, according to Rhoades: ${ }^{32}$

'In the farmer-back-to-farmer approach we are more flexible in methodology, using anything that we believe works. Thus, we might even start by conducting experiments with farmers just to learn about a problem. We believe in the rapid appraisal methodology (informal), but we even use the sondeo in evaluating impact. Rigid, 
step-wise field methodologies have never worked for us. It is more the philosophy that counts.'

Turning now to the four FFL approaches outlined above, some of their main distinguishing features are:

Rapid and cost-effective appraisal

Holistic farming systems analysis, including the farm household and its needs

Appraisal

Learning from farmers

Inter-disciplinarity with genuine dialogue.

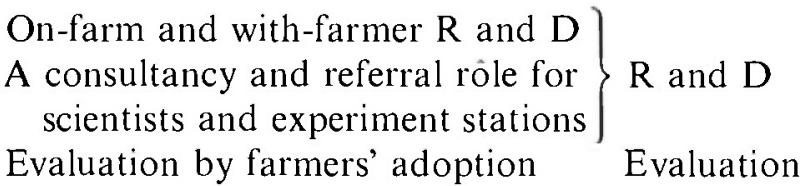

The four have much in common on these lines, but each has its special emphases. These can be presented as follows:

Special Emphases in Different Farmer-Fir'st-and-Last Methodologies

CIMMYT Sondeo ICRAF CIP Farmerand $\quad D$ and $D$ back-to-farmer

Collinson $^{13}$

\begin{tabular}{|c|c|c|c|c|}
\hline RPF family focus & & & $\times$ & \\
\hline Learning from farmers & $\times$ & & & $x$ \\
\hline $\begin{array}{l}\text { Rapid appraisal } \\
\text { methodology }\end{array}$ & $\times$ & $x$ & $\times$ & \\
\hline Combining disciplines & $x$ & $x$ & $\times$ & $x$ \\
\hline $\begin{array}{l}\text { On-farm with-farmer } \\
\text { experiments }\end{array}$ & $\times$ & $\times$ & & $x$ \\
\hline $\begin{array}{l}\text { Consultancy and } \\
\text { referral rôle of scientists } \\
\text { and research stations }\end{array}$ & & & & $\times$ \\
\hline $\begin{array}{l}\text { Evaluation by farmers' } \\
\text { adoption }\end{array}$ & & & & $x$ \\
\hline
\end{tabular}

Note: $\times$ indicates special emphasis in the methodology. It is not evaluative, and the number of $x$ 's does not indicate a score or rating. 
The absence of unequivocal 'special emphases' against 'R PF family focus' reflects a lack of explicit priority to RPF families. All four approaches include the definition of a reasonably homogeneous clientele group, often described as a 'recommendation domain'. This may include many RPFs, but, with possible exception of ICRAF's D and D, the smaller and poorer farmers do not appear to have been deliberately sought out in these approaches. It seems quite likely that many of the farmers interviewed and worked with will have been among the somewhat better off. These farmers may be subject to the same physical constraints of soils, and rainfall, but may differ from R PFs in their cash resources, access to inputs and credit, scale of operation, storage facilities, need for subsistence, and so on. Small and marginal farmers face their own specific problems, in resource-poor zones as elsewhere, and these four approaches do not, in themselves, guarantee that their conditions and needs will be catered for. A deliberate and difficult effort has to be made to include them.

From these examples, the three major components of a farmer-firstand-last model can be identified as: (i) diagnostic procedure, learning from farmers; (ii) generating technology on-farm and with-farmer and (iii) evaluation of technology by its adoption or non-adoption by farmers.

\section{Diagnosis}

The point about diagnosis preceding the determination of research priorities has been forcefully made by Lundgren and Raintree ${ }^{21}$ in justifying ICRAF's D and D methodology:

'It is a cardinal rule in the medical profession that diagnosis should precede treatment. In practice, there are exceptions to this rule, of course, but it would be unthinkable for doctors ever simply to ignore the diagnostic process altogether, and prescribe treatment without due regard for the specific nature of the patient's illness. We would hardly tolerate a haphazard, hit-or-miss approach to treatment from professions dealing with human pathologies. How strange, then, that we have come to accept such an approach when it comes to treating pathologies arising from man's use of the earth. Is this not, in fact, what happens when a traditional agricultural or forestry research station develops a new technology and recommends it for dissemination? In how many instances is the treatment preceded by adequate diagnosis of the actual and perceived problems which confront the majority of land-users in the recommendation domain? 
The answer of many researchers, that they 'already know what the problems are' without having to bother with the complications of a formal diagnostic procedure, is analogous to a doctor's making either the patently absurd assumption that all patients are the same, or his claiming arrogantly that a well-trained practitioner is able to treat patients without recourse to an examination.'

There is now a substantial literature on rapid appraisals* but much scope for inventiveness remains. The Art of the Informal Agricultural Survey is one key element. ${ }^{29}$ What has formerly been regarded as something anyone can do is now seen as a set of skills which can, and should, be learnt. Problems are posed where multi-disciplinary teams cannot be assembled, and methods and training are required for agricultural scientists who have perforce to conduct such appraisals on their own.

\section{$R$ and $D$ on-farm and with-farmer}

There are tests and experiments which require strictly controlled conditions and precise measurements which are most feasible on research stations, in glasshouses and in laboratories. But if the $\mathrm{R}$ and $\mathrm{D}$ process is confined to such conditions, the constraints, resources, complexities and stresses of the farm level, and the criteria and priorities of the farm family, are automatically excluded from the generation and screening of technology. Characteristics of the evolving technology will reflect the objectives and criteria of scientists, the resources of the research station and the controlled environment. Features of the evolving technology which might better fit farmers' needs and conditions may often not be included. Small farmers also have a widespread capacity to experiment and innovate themselves as Brammer ${ }^{6}$ has vividly illustrated from Bangladesh, and can contribute as professional colleagues to the R and D process.

The example of potato storage technology in Peru illustrates this point. ${ }^{30.31}$ At first, scientists worked on potato storage generally, but farmers defined their problem more precisely as the sprouting of stored seed potatoes. When this became the priority problem, scientists worked on-station on the known scientific principle that natural diffused light reduces sprout growth and generally improves seed quality. At the same * See Agricultural Administration 8(6) (1981), and, for a list of some sources, Chambers, $1981^{2.10}$ 
time, ways of applying the principle were worked out with farmers and in their houses, using materials available to farmers and fitting in with traditional house architecture. Improvements in storage were achieved and the new technology was adopted and spread, with farmers making further adaptations.

Had the locus of application of the principle not been the farmer's houses, the classical problems of trying to transfer a research station technology might well have arisen, and scientists and extension staff might, to this day, still be struggling to persuade farmers to adopt a technology appropriate for the research station but not for farmers' conditions. As it was, finding out and meeting the farmers' perceived problems, and the joint collaboration of farm family and scientist in the farm environment, ensured that adoptability was built into the technology development process itself.

Another example is of maize on-farm research at Pantnagar (in India ${ }^{1}$ ). Hybrid maize with a high yield potential was not accepted by the farmers. With maize 'on-farm' research trials a direct and effective dialogue between researchers and farmers was established. One reason for nonadoption that emerged was that the soil and climatic conditions of Pantnagar did not represent those of farmers. Another was that farmers' varieties had better adaptability and grain quality. With a change in breeding priorities resulting from the on-farm work and the dialogue, new varieties could be developed which were acceptable to the farmers.

An even more recent example of promising methodological innovation is reported from Colombia from a special project on the participation of small farmers in on-farm testing. ${ }^{3}$ For fertiliser trials, three methods were distinguished as follows:

\begin{tabular}{lllc}
\hline $\begin{array}{c}\text { Type of participation } \\
\text { of farmers }\end{array}$ & \multicolumn{1}{c}{$\begin{array}{c}\text { Trial } \\
\text { Designed by }\end{array}$} & $\begin{array}{c}\text { Trial management } \\
\text { Defined by }\end{array}$ & Implemented by \\
\hline Nominal & Research & Research & Research \\
Consultative & Research & Research & Farmer \\
Decision-making & Farmer and & Farmer & Farmer \\
& research & & \\
& & & \\
& & &
\end{tabular}

These three were in parallel and compared. With consultative participation there were two problems: either farmers were reluctant to 
manage, wanting research staff to tell them what to do; or they 'ruined' the trial from the researcher's point of view. Ashby concludes that farmerimplemented trials in the consultative mode can seldom be truly representative of what farmers would do on their own, leaving as a problem how much yields should be discounted to reflect that they are still experimental yields and not really farmer yields.

An early step with the third approach, decision-making participation of farmers, was for the scientist researchers to reverse roles and learn from the farmers. Farmers were asked to teach them their local techniques for planting and fertilizing beans:

'In a practical teaching situation, often in the fields with traditional tools, it is soon apparent how clumsy, slow-on-the-uptake, and inexpert researchers can be in terms of the farmers' traditional technology. The agronomist, trained to instruct farmers, suffered in this situation: his automatic reaction, as an expert, was to argue with farmers and point out how things should be done. The rôle conflict experienced by the agronomist was indicative of the breakdown of social conventions of farmer-expert interaction. ${ }^{3}$

Later, the proposed fertiliser technology was discussed with the farmers. The questions farmers wanted answered were listed. The researchers had wanted to evaluate rock phosphate under farmers' conditions and to compare response curves for three different phosphate sources. In contrast, farmers wanted to know the potential of mixtures of phosphates and chicken manure. The scientists who developed the research design preferred not to test with mixtures and organic fertilisers because of the difficulties of controlling and interpreting nutrient responses from different sources. However, the soils scientist did prepare a research design in consultation with the farmers. For this, the research agenda, the questions to be answered, were those of the farmers.

\section{Evaluation by adoption}

The final element in FFL is evaluation by RPFs themselves. The test of a new technology is not yield on a research station or on the land of a resource-rich farmer, or even on an RPF's land, but whether RPFs actually adopt it. For this to occur, the technology must usually entail direct satisfaction of the perceived needs of the family, low risk, and low, or no, reliance on purchased inputs. These, we argue, are much more likely 
features of the technology when its generation has been preceded and determined by diagnosis and by on-farm and with-farmer $\mathrm{R}$ and $\mathrm{D}$, than with the TOT model.

\section{REVERSALS OF EXPLANATION, LEARNING AND LOCATION}

FFL entails reversals of explanation, learning and location.

The reversal of explanation concerns non-adoption. There can be seen to be three levels, or stages, of explanation of non-adoption of new technology by farmers. These are presented in Table 3 .

TABLE 3

Non-Adoption: Changes in Explanation and Prescription

\begin{tabular}{|c|c|c|c|c|}
\hline $\begin{array}{l}\text { Level or } \\
\text { stage of } \\
\text { explanation }\end{array}$ & Model & $\begin{array}{c}\text { Period when } \\
\text { dominant }\end{array}$ & $\begin{array}{l}\text { Explanation of } \\
\text { non-adoption }\end{array}$ & Prescription \\
\hline 1 & TOT & $1950 \mathrm{~s}, 1960 \mathrm{~s}$ & $\begin{array}{l}\text { Ignorance of } \\
\text { farmer }\end{array}$ & $\begin{array}{l}\text { Agricultural extension } \\
\text { to transfer the } \\
\text { technology }\end{array}$ \\
\hline 2 & TOT & $1970 \mathrm{~s}, 1980 \mathrm{~s}$ & $\begin{array}{l}\text { Farm-level } \\
\text { constraints }\end{array}$ & $\begin{array}{l}\text { Ease constraints to } \\
\text { enable farmers to } \\
\text { adopt the technology }\end{array}$ \\
\hline 3 & FFL & $\begin{array}{l}\text { Latter 1980s } \\
\text { for RPFs? }\end{array}$ & $\begin{array}{l}\text { The technology } \\
\text { does not fit } \\
\text { RPF conditions }\end{array}$ & $\begin{array}{l}\text { FFL to generate } \\
\text { technology which } \\
\text { does fit RPF } \\
\text { conditions }\end{array}$ \\
\hline
\end{tabular}

The major reversal is that explanation of non-adoption shifts from deficiencies of the farmer and the farm level, to deficiencies in the technology and in the technology-generating process.

The reversal of learning requires that scientists start by systematically learning from farmers, with transfer of technology from farmer to scientist as a basic and continuous process.

The reversal in location requires that $\mathrm{R}$ and $\mathrm{D}$ take place on-farm and with-farmer, with research stations and laboratories in a referral and consultancy rôle.

The nature of these reversals is illustrated in Table 4. With FFL for RPFs, the contrast in location and activities can be illustrated diagrammatically, as shown in Table 5. 
Each model has its major problem. That of TOT is the transfer of inappropriate technology to resource-poor farmers. That of FFL is the transfer of inappropriate scientists to resource-poor conditions. In the first case the technology, and, in the second, the scientists, bear the deep imprint of resource-rich conditions. For FFL to be feasible requires changes among scientists. These entail a sort of psychological 'flip', seeing the world the other way around, as the RPF family does; or as psychologists sometimes say, 'taking hold of the other end of the stick'.

The mental set for FFL is thus radically different from that of TOT. It has been well stated by Rhoades and Booth in their own farmer-back-tofarmer approach:

'The basic philosophy upon which the model is based holds that successful agricultural research and development must begin and end with the farmer. Applied agricultural research cannot begin in

TABLE 4

Contrasts in Learning and Location

\begin{tabular}{|c|c|c|}
\hline $\begin{array}{l}\text { Research priorities and } \\
\text { conduct determined } \\
\text { mainly by }\end{array}$ & $\begin{array}{l}\text { TOT } \\
\text { Needs, problems, per- } \\
\text { ceptions and environment } \\
\text { of scientists }\end{array}$ & $\begin{array}{l}\qquad F F L \\
\text { Needs, problems, per- } \\
\text { ceptions and environment } \\
\text { of farmers }\end{array}$ \\
\hline Crucial learning is that of & Farmers from scientists & Scientists from farmers \\
\hline Ròle of farmer & 'Beneficiary' & $\begin{array}{l}\text { Client and professional } \\
\text { colleague }\end{array}$ \\
\hline Ròle of scientist & Generator of technology & $\begin{array}{l}\text { Consultant and } \\
\text { collaborator }\end{array}$ \\
\hline Main $\mathrm{R}$ and $\mathrm{D}$ location & $\begin{array}{l}\text { Experiment station, } \\
\text { laboratory, glasshouse }\end{array}$ & $\begin{array}{l}\text { Farmers' fields and } \\
\text { conditions }\end{array}$ \\
\hline $\begin{array}{l}\text { Physical features of } \\
R \text { and D mainly } \\
\text { determined by }\end{array}$ & $\begin{array}{l}\text { Scientists' needs and } \\
\text { preferences, including } \\
\text { statistics and experimental } \\
\text { design }\end{array}$ & $\begin{array}{l}\text { Farmer's' needs and } \\
\text { preferences }\end{array}$ \\
\hline & Research station resources & Farm-level resources \\
\hline $\begin{array}{l}\text { Non-adoption of } \\
\text { innovations explained by }\end{array}$ & $\begin{array}{l}\text { Failure of farmer to learn } \\
\text { from scientist } \\
\text { Farm-level constraints }\end{array}$ & $\begin{array}{l}\text { Failure of scientist to learn } \\
\text { from farmer } \\
\text { Research station } \\
\text { constraints }\end{array}$ \\
\hline Evaluation & $\begin{array}{l}\text { By publications } \\
\text { By scientists* peers }\end{array}$ & $\begin{array}{l}\text { By adoption } \\
\text { By farmers }\end{array}$ \\
\hline
\end{tabular}


TABLE 5

Activities and Their Location

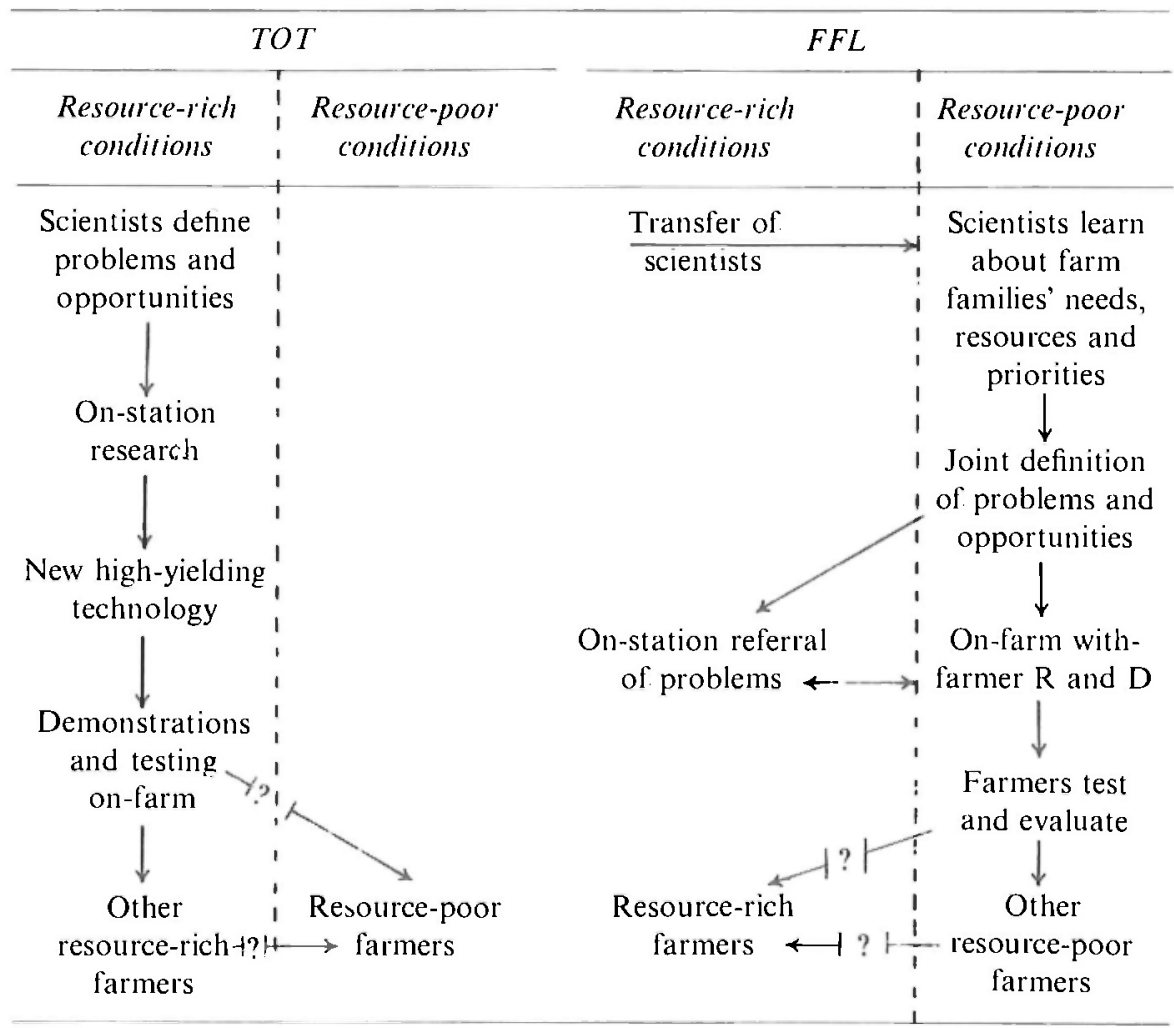

isolation on an experimental station or with a planning committee out of touch with farm conditions. In practice, this means obtaining information about, and achieving an understanding of, the farmer's perception of the problem and finally to accept the farmer's evaluation of the solution...'

(Rhoades and Booth ${ }^{30}$ page 132 . Their emphases)

\section{PRACTICAL IMPLICATIONS}

\section{Obstacles to adoption by scientists}

To adopt and adapt the FFL approach on any scale, stressing R PFs, will be difficult. The TOT model is very stable, with inbuilt buffering against 
change. Systematic learning from farmers is not a part of professional training. Multi-disciplinary teams are difficult to muster, and truly interdisciplinary collaboration is not easy. Social scientists are often either not available, or liable to have narrow concerns and orientationcosts of cultivation, social cost-benefit analysis, and so on-which fall short of an understanding of farming systems. Then resources (vehicles, allowances, village-level staff, stores for inputs, etc.) for extended fieldwork in appraisals and work on-farm and with-farmer are often not easily available. Work on research stations or on larger farmers' fields is more easily and conveniently controlled, inspected, measured and shown to others. For some scientists, it may quite simply be uncongenial to spend time with farmers, let alone with those who are resource poor. Onstation work may also more readily and predictably lead to publishable papers which advance a scientist's career and lead, in a conventional manner, to national and international recognition. Professional values take modern scientific knowledge as superior, advanced and sophisticated, and little appreciate or respect the knowledge of farm families. TOT can, in sum, be convenient and gratifying, allowing scientists to conduct their elite and clean work in controlled quasi-laboratory conditions, passing to others - extension staff and social scientists--the messy and lower status work of transferring the technology, educating the farmer and overcoming whatever constraints to diffusion and adoption there may be.

\section{Five thrusts}

Innovations with parts or variants of FFL have doubtless already been developed in various places in India, and others may be planned, as with the ICRAF D and D methodology in the All-India Coordinated Research Programme for Agro-forestry. Any attempt to develop and introduce the FFL model on a wider scale can be seen to require five complementary thrusts.

\section{Methodological innovation}

Eclectic use of elements of methods already developed elsewhere need to be combined with innovation in and for local conditions, with special stress on resource-poor areas and farm families. By analogy with the collection of genetic material, methodological material needs to be collected from different environments. Access is needed to relevant 
experience in other countries, and some of this is already available in journals.

\section{Interdisciplinarity}

Full interdisciplinarity entails collaboration between farmers, technical scientists and social scientists. In practice, it is rare for either technical scientists or social scientists to be properly equipped for this sort of work. Moreover, social scientists are usually hard to get hold of. Few institutions can muster a combination of, say, agricultural sciences, farming-systems-oriented agricultural economics and sociology and social anthropology. The best feasible course of action may often be that farmers and agricultural scientists together do the best they can.

\section{Resources}

Rapid appraisals require resources for travel and work out of station, as does on-farm and with-farmer $\mathrm{R}$ and $\mathrm{D}$. Vehicles and funds for travel are not always absolutely essential but, in practical terms, their availability will often be a precondition for effective FFL work.

\section{Revards}

Apart from exceptional individuals, scientists need to feel that they will be rewarded for behaviour which is both inconvenient and liable to be less productive initially in professional terms; for example, publications. One measure is to encourage self-critical writing about experience with the FFL approach and with methodologies such as rapid appraisals. Another is to recognise exceptional work in this field through promotions and rewards, putting it on a par with high status genetic and microbiological work. An annual competition with an award for the best FFL R and D is one way of doing this.

\section{Training}

How to learn from farmers, like how to manage an organisation, is a set of skills that most people think they have; but, like management, learning from farmers has specialised techniques and can be taught and learnt (see for example Rhoades). ${ }^{29}$ Techniques for diagnostic survey, analysis and design can also be taught. University curricula can be developed to include farming systems. Attitude changes are more difficult, but simulation games like 'Green Revolution' and 'Monsoon' can help, and 
further simulation games in which scientists play RPFs could be devised. ${ }^{12,37}$

Success will depend critically on the style and quality of the face-to-face relationships of scientists and farmers. For this, there is no substitute for learning by doing. Unless that relationship is truly one of scientists diligently learning from farmers, in a humble rôle, only the form of farmer-first-and-last will be achieved, and not the substance. The most essential element is learning by doing, with colleagues correcting each other if they slip into the habitual roles of teacher instead of learner.

\section{CONCLUSION}

Among scientists, changes of model or shifts of paradigm are sometimes described as revolutions. They entail seeing the familiar in an entirely new way and they are usually resisted by professional establishments. The five thrusts above also do not fit current staffing resources, orientation and training. To develop new FFL methodologies requires special institutional conditions. It is striking how strongly the orientation and conditions needed resemble those found in a recent study of America's best-run companies such as a basis for action, learning from the customer, encouraging risk-taking and tolerating mistakes, and valuing and giving sustained support and resources to innovative individuals. ${ }^{27}$ In contrast, in hierarchical organisations with strict norms about resources available, behaviour and conformity, such revolutions in orientation and behaviour are difficult.

If, however, our argument is correct that FFL offers a more costeffective way of generating technology adoptable by RPFs, then the question is not whether, but how, it can be developed and introduced. One approach is to create special multi-disciplinary units for methodological innovation. Another is to provide additional resources to existing groups which wish to undertake and develop FFL approaches. The professional incentives for far-seeing scientists should be strong. The model challenges them to develop new methodologies. In the longer term there is a promise of professional recognition and rewards for those who pioneer. Above all, there should be the profound satisfaction of developing technologies which do truly enable many resource-poor farm families to secure a better livelihood from agriculture. 


\section{ACKNOWLEDGEMENT}

This paper is a revised version of one prepared for the National Agricultural Research Project Workshop on National Agricultural Research Management at the National Academy of Agricultural Research Management, Rajendranagar, Hyderabad, India, July 10-13, 1984. The views expressed are those of the authors and not necessarily those of the Ford Foundation. For comments on the earlier version of this paper we are grateful to participants in the Workshop and to William Bentley, Michael Collinson, John Harriss, Peter Hildebrand, Janice Jiggins, Jacob Kampen, Gilbert Levine, Simon Maxwell, Robert E. McDowell, David Nygaard, John Raintree, Robert Rhoades and S. L. Shah.

\section{REFERENCES}

1. Agrawal, B. D., Maize On-farm Research Project (1982 Report), G. B. Pant Krishi Evam Praudyogik Vishwavidyalaya, Pantnagar, 263145, 1983.

2. Agricultural Administration, Special issue on rapid rural appraisal, 8(6) (November, 1981).

3. Ashby, Jacqueline A., Participation of small farmers in teclmology assessment, IFDC-CIAT Phosphorus Project, A. A. 6713, Cali, Colombia, South America, 1984.

4. Benor, D. and Baxter, M. Training and Visit Extension, The World Bank, 1818 H Street, NW, Washington, DC, 20433, USA.

5. Biggs, Stephen D., Monitoring and control in agricultural research systems maize in Northern India, Research Policv, 12(1) (February, 1983), pp. $37-59$.

6. Brammer, H., Some innovations do not wait for experts: A report on applied research by Bangladesh peasants, Ceres, 13(2) (1980).

7. Byerlee, Derek and Collinson, M., Planning techmologies appropriate to farmers - Concepts and procedures, CIMMYT, Mexico, 1980.

8. Byerlee, Derek, Harrington, Larry and Winkelmann, Donald L. Farming systems research: Issues in research strategy and technology design, American Journal of Agricultural Economics (December, 1982), pp. 897-906.

9. Catling, H. D. How relevant is agricultural research on conventional experiment stations in developing countries? Paper read at the Regional Workshop on Research and Technology Transfer for Asian Development, November 1-3, Bangkok, Thailand. 1983.

10. Chambers, Robert, Rapid rural appraisal: Rationale and repertoire, Public Administration and Developmem, 1(2) (April-June, 1981). 
11. Chambers, Robert, Rural development: Putting the last first, Longmans, Harlow, UK, 1983.

12. Chapman, Graham, The evolution and impact of the Green Revolution Game and Exaction, Report commissioned by the Economics and Policy Division of the World Bank, 1983.

13. Collinson, Michael, A low cost approach to understanding small farmers, Agricultural Administration, 8(6) (1981), pp. 433-50

14. De Dutta, S. K., Gomesh, K. A., Herdt, R. W. and Barker, R. A handbook on the methodology for an integrated experiment-survey on rice yields constraints, International Rice Research Institute, PO Box 933, Manila, Philippines, 1978.

15. Gilbert, E. H., Norman, D. W. and Winch, F. E., Farming systems research: A critical evaluation, MSU Rural Development Paper No. 6, Department of Agricultural Economics, Michigan State University, East Lansing, Michigan, 1980.

16. GOI-IRRI. Report of Production Oriented Survey on Rice in Problem Areas of Bihar, Orissa and West Bengal, Indian Council of Agricultural Research, Krishi Bhavan, New Delhi, 1977.

17. Hildebrand, Peter, Combining disciplines in rapid appraisal: the Sondeo approach, Agricultural Administration, 8(6) (1981), pp. 423-32.

18. ICAR. Research Highlights, Indian Council of Agricultural Research, Krishi Bhavan, New Delhi 110001, 1981.

19. ICAR. All India Coordinated Agronomic Research Project, Anmual Report, 1981-82, Indian Council of Agricultural Research, University of Agricultural Sciences, Bangalore, 1983.

20. Kalra, B. R., Size and distribution of operational holdings, Kurukshetra (September, 1981), pp. 4-10.

21. Lundgren, B. and Raintree, J. B. Agroforestry. In: Agricultural research for development: potentials and challenges in Asia, (Nestel, B. (Ed.)), International Service for National Agricultural Research, The Hague, Netherlands, March, 1983, pp. 37-49.

22. Maxwell, Simon. Farming systems research, Institute of Development Studies, University of Sussex, Brighton, Great Britain (February, 1983).

23. Maxwell, Simon, Personal communication of a one-page chart. 'The Farming Systems Research Methodology', Institute of Development Studies, University of Sussex, Brighton, Great Britain, March, 1984.

24. Norman, David, Farming systems research to improve the livelihood of small farmers, American Journal of Agricultural Economics, 60(5) (1978).

25. Norman, David. The farming systems approach: Relevancy for the small farmer, MSU Rural Development Paper No. 5, Department of Agricultural Economics, Michigan State University, East Lansing, Michigan 48824, USA, 1980.

26. Nygaard, David F. and Rassam, Andree. Examples of farming systems research at ICARDA. Paper presented at a conference on Intra-household Processes and Farming Systems Analysis, Bellagio, Italy, March 5-9, 1984. 
27. Peters, Thomas J. and Waterman Jr., R. H. In search of excellence: Lessons from America's best-run companies, Harper and Row, New York, 1982.

28. Raintree, J. B. and Young, A. Guidelines for agroforestry diagnosis and design, ICRAF Working Paper No. 6, International Council for Research in Agroforestry, PO Box 30677, Nairobi, Kenya, November, 1983.

29. Rhoades, Robert E., The art of the informal agricultural survey, Social Science Department Training Document 1981, International Potato Center, Aptdo 5969, Lima, Peru, March, 1982.

30. Rhoades, Robert E. and Booth, Robert H. Farmer-back-to-farmer: A model for generating acceptable agricultural technology, Agricultural Administration, 11(2) (1982), pp. 127-37. (Also available as Social Science Department Working Paper 1982-1, International Potato Center, Aptdo 5969, Lima, Peru.)

31. Rhoades, Robert E., Three models of the development and generation of acceptable agricultural technology, Typescript, International Potato Center, Aptdo 5969, Lima, Peru, 1984.

32. Rhoades, Robert E., personal communication, 12 March, 1984.

33. Sanghi, N. K., Operational research in dryland agricullure for semi-arid red soils of Hyderabad, Project Bulletin No. 3, All-India Co-ordinated Research Project for Dryland Agriculture, Hyderabad 500659, 1982.

34. Sen, Amartya, Poverty and famines: An essay on entitlement and deprivation, Clarendon Press, Oxford, 1981

35. Sen, Amartya, 'Food battles-Conflicts in access to food', Twelfih Coromandel Lecture, Coromandel Fertilisers Ltd, 10 Parliament Street, New Delhi $110001,1982$.

36. Shaner, W. W., Philipp, P. E. and Schmehl, W. R., Farming systems research and developmemt: Guidelines for developing coumries, Westview Press, Boulder, Colorado, 1982.

37. Staley, John, Monsoon: A Simulation Game, SEARCH, 256 First Block, Jayanagar, Bangalore 560011, 1981.

38. Swaminathan, M. S., Science and integrated rural development, Concept Publishing Co., New Delhi, 1982.

39. Swaminathan, M. S., Science and the conquest of hunger, Concept Publishing Co., New Delhi, 1983. 